\title{
International Convergence of Fair Value in Chinese Accounting Standards
}

\author{
Fenglin Peng \\ Jianghan University, Wuhan, China
}

\begin{abstract}
With the transformation of China's economy from a planned economy into a market economy, Chinese accounting has developed rapidly for decades. As a guideline and regulation for accounting theory and practice, China's accounting standards are also undergoing reform and innovation. This paper analyzes the international convergence of the definition of fair value in China, and the international convergence of fair value application in Chinese Accounting Standards, explores the future outlook of fair value usage in Chinese Accounting Standards in the context of international convergence, expounds the application of fair value in Chinese accounting standards, and reflects the remarkable way in which the accounting standards of our country are in line with international practice. Finally, the paper points out that we must go to our country's own economic development road unswervingly, but not blindly copy other countries' international practice. Additionally, we should adapt to the development trend of world economic of integration and realize the international convergence when conditions are ripe, so as to promote the positive effect to our economy.
\end{abstract}

Keywords: fair value, accounting standards, international convergence

\section{Introduction}

The transformation of China's economy from a planned economy into a market economy is also the process of the development of accounting standards for Chinese enterprises. As an important part of the market economy, China's accounting has also undergone tremendous changes in this period of history, so as to adapt to and actively promote the development of China's market economy. Its influence is remarkable, and the contribution has been well known. In recent years, the economy not only focuses on the development road of Chinese characteristics, but also because of the trend of economic globalization and integration of capital market, Chinese enterprises are also gradually joining into the world economy integrated circle. Therefore, as one of the foundations of enterprise management, accounting is bound to be greatly influenced by international accounting standards. At the same time, the consciousness of opening and internationalization of Chinese enterprise management has been greatly improved, and the quality of accountants and auditors has been continuously enhanced. Based on the comprehensive assessment and assurance of the environment and abroad, China's Ministry of Finance and the China Accounting Standards Committee have formulated international standards in line with China's national conditions and actively promoted international convergence of

Fenglin Peng, associate professor, Business School of the Jianghan University, Wuhan, China.

Correspondence concerning this article should be addressed to Fenglin Peng, No. 8 Triangle Lake str., Wuhan Economic \& Technical Development Zone, Wuhan 430056, China. 
accounting standards. The adoption of fair value is a typical reflection of our country's unremitting exploration of the international convergence of accounting standards.

At present, fair value is still an irreplaceable measure of asset value, which helps to truly reflect the capital situation of enterprises. Chinese implementation and international convergence of the new accounting standards show from one side to the world, "Chinese accounting has experienced 30 years of reform and opening up the unremitting efforts” (Liu, 2009), in some aspects has joined the advanced ranks in the world. These changes reflect China from implementation of the planned economy, to the implementation of the international market economy, which is a true portrayal of China's reform and opening up fruitful.

During the formulation and development of China's accounting standards, China's attitude towards fair value can be broadly summarized as follows: "no, yes, no, reuse”. One cannot help asking why the adoption of fair value has been repeated many times. Why does the application of fair value in China's accounting standards reflect precisely that China's accounting standards are trying to explore a way of international convergence with Chinese characteristics?

To answer these questions, we should begin with the essence of fair value.

\section{International Convergence of the Definition of Fair Value in China}

\section{Definitions of Fair Value by IASC and FASB}

For the definition of fair value, different institutions have different definitions. IASC released in 1999 the "International Accounting Standards No. 39-financial instruments: recognition and measurement”, in which, it pointed out,

In the definition of fair value an assumption implies that the enterprise is going, do not plan or do not need to be liquidated, greatly reduced the size of its operations, or according to the unfavorable conditions of trade. Therefore, fair value is not the amount received or paid by an enterprise in a mandatory transaction, involuntary liquidation or loss sale. (IASC, 1999)

FASB in February 2000 issued No. 7 Announcement on the concept of fair value, which said "fair value is price of, in the current non-forced transaction or non-clearing transactions, assets (or liabilities) between the two sides of voluntary sale (or the occurrence of settlement)" (FASB, 2000).

\section{The International Convergence of China's Standards on the Definition of Fair Value}

As we all know, China's long-term measurement base is based on historical costs based on traditional measurement model. The historical cost measurement model has been used all over the world for hundreds of years, and has always been the dominant position in modern accounting. Before 1970s, the traditional financial accounting based on historical cost was used more smoothly. This is because the historical cost accounting model meets the needs of people's reliability of information. But since then, the rapid development of the western financial derivatives has made people realize that the historical cost measurement model cannot meet the needs of economic development more and more. First of all, some derivative financial instruments cannot be recognized and measured. For example, forward and swaps do not have to be paid in cost, and cannot be measured in terms of historical cost definitions. In addition, some derivative financial instruments are quite complex and cannot be measured with historical costs. Second, some derivative financial instruments, even though they can be measured with historical costs, reflect a very weak correlation. Because the derivative financial instruments can not reflect the huge risks or benefits that exist during the period of existence, they 
often mislead the information users. For example, for enterprises, engaging in financial derivatives trading has been facing a huge risk. The financial data not only fail to reflect the historical cost in the crisis before the arrival of an early warning role, but in the actual business have deep financial difficulties, meanwhile, still show good business. Thus, one measurement model which can reflect the real financial situation of the enterprise is required, and the fair value measurement model, a new, based on the current market price emerged. As mentioned in the Chinese guidelines before 2014, the so-called fair value referred to the total amount of assets and liabilities, which are measured by voluntary exchange of assets or debt settlement by the parties who are familiar with the situation in fair trading. It can be seen that fair value emphasizes the fairness and recognition of measurement, and it has a strong correlation with the actual market value of assets or liabilities. But due to the relevant market in China which is not mature, the market transaction is not active, the dependence with the "mature market economy" said by international financial reporting standards is so far. So how to confirm the fair value is a problem. This definition above gives full consideration to the basic national conditions and meets the needs of the market in our country.

On January 6, 2014, the Ministry of Finance of the PRC formulated the accounting standards for Enterprises No. 39-fair value measurement, which stipulates that it shall be implemented from July 1st of that year. The new definition of fair value is the same as the original standard definition, which is based on the assumption of fair trading in active markets (that is not actually sold or forced to trade or sell). However, the original definition of fair value does not specify whether the entity is buying assets or selling assets, and the meaning of the debt is not clearly defined because it does not refer to creditors and only refers to voluntary traders who are familiar with the situation. Also, it is not clear whether exchange or liquidation occurs on or off the date of measurement.

The revised definition of fair value compensates for these deficiencies. The definition is also further clear, that fair value measurement is based on the market and not the specific subject of fair value measurement, and reflects the current market conditions.

In contrast to the old and new definitions, we note the first appearance of the "disposal price" in the definition of fair value. As we all know, the definition of fair value has been a lot of controversy. The revised basic principle defines fair value as "selling price”, which will help all circles to recognize each other. Also, the "orderly transaction" in the definition is replaced by "fair trade". The "fair" is accepted voluntarily by both sides, and cannot represent the whole market of fair recognition, also cannot be used as the symbol of fair value. Stability and "orderly" emphasize the market order and performance of the transaction, reflecting the result of the game being played widely of the market.

These changes in the definition of fair value are important development of convergence of our country's accounting standards and international standards. IASB released in 2009 the "fair value" criterion (Draft), the basic use of the FASB in 2007 released a statement of financial accounting standards "fair value measurement" (FAS157) in the definition of fair value, namely "the price paid by market participants at the measurement date in an orderly transaction from asset sales receipt or for debt transfer”.

\section{The International Convergence of Fair Value Application in Chinese Accounting Standards} The Development and Application of Fair Value by IASC and FASB

In 1990, as the most developed market economy in the world and the forefront of the study of accounting standards, the United States used fair value as a measurement attribute of financial instruments for the first time. 
Then the United States authority, FASB developed accounting standards. Since March 1990 it issued SFAS105 "related financial instruments balance sheet risk and information risk disclosure", to September 2000, a total of more than 10 issued announcements, made it clear that the fair value measurement attribute is the best measurement of financial instruments. As a result of the change of attitude of American FASB, many western countries, such as the United Kingdom, have adopted the concept of fair value in the development of modern accounting standards. After 1990s, the international accounting standards board (IASC) began to accept the FASB's point of view, recognized it is an irresistible trend and development direction in a certain extent that the fair value replaces the historical cost measurement which has been used for a long time. From the current international accounting standards and the United States financial accounting standards, the use of fair value measurement of all derivative financial instruments has become the common goal of IASC and FASB. Moreover, in the development of accounting standards in developed countries such as IASC countries, America, and Britain, the use of fair value presents a convergence from derivative financial instruments to other fields, such as from financial areas to non-financial areas, from current asset projects to long-term asset projects, and from current liabilities projects to long term liabilities projects.

These changes in fair value are due to the two characteristics of fair value: (1) reflects the real value of a certain period of time on the value of assets or liabilities, for evaluating the true economic benefits brought by assets to the enterprise or the value of debt at the time of transfer; (2) as the foundation to the parties under the transaction which can be understood and free, and the even bargain without any influence.

\section{The International Convergence of China's Standards on the Development and Application of Fair Value}

(1) The first use of fair value, choose the same path with international accounting standards.

When the study of fair value in western developed countries is raging, the acceptance and application of fair value by China's accounting standards is not smooth sailing. As the market economy started relatively late, China's acceptance of the concept of fair value is much later than that of western countries, such as the United States and Britain. In 1998, China introduced the accounting standards for enterprises-debt restructuring, which used the fair value measurement attributes for the first time. After that, the fair value was used as a measurement model in the two criteria relating to non-monetary transactions and investment.

There are important reasons for the acceptance and use of fair value in our country at this stage. At this stage, China's economy has gradually completed the transition from a planned economy to a market economy, and the establishment of a modern enterprise system is in full swing. The securities and other investment markets are beginning to emerge from infancy to prosperity. Although compared with the western developed countries in varieties or trading volume, the stage of China's financial instruments is still in the initial, the enterprise and the academic circles gradually realized the importance of integration with the international accounting standards. At this time, fair value research which has already been the concern of the academic circles of the world has become the concern of our country, coupled with China's domestic enterprises' increasing change, restructuring and financial investment activities, and the increasingly prominent issues caused by the traditional historical measurement as well. All of these cases will make China's Accounting Standards Department look to the international practice, introducing fair value measurement model to improve a series of problems encountered in the reform of our enterprises, and in the use of measurement attributes on the choice and the convergence of international accounting standards.

(2) Avoid fair value, and there are differences with international accounting standards. 
The fair value, which has been promoted since 1998, was urgently halted by the Ministry of Finance from the accounting standards in January 2001. The introduction of fair value in the standards, such as the aforementioned related debt restructuring, non-monetary transactions, investment criteria, treatment for economic and business transactions is avoided and the use of book value is recommended. The revised Chinese Accounting Standards greatly reduces the use of fair value.

The reasons why fair value measurement in China's accounting standards is on the departure from the international norms of the method, mainly are the following points:

Firstly, fair prices are difficult to be "fair". Although Chinese reform and opening up has greatly promoted the development of the market economy, it is still an emerging market economy. So it is still in the initial stage. Both production market and property market need to further improve and perfect. Compared with the developed countries in the world which have the environment of even bargain after hundreds of years of development to market economy, there is still a big gap. In this case, it is difficult that the true fair value of reliable physical assets, financial assets, intangible assets can be achieved, and it is prone to related party transactions which are used to provide space for their manipulation of accounting profits. In order to avoid the further deterioration of the quality of accounting information, the accounting standards make Department of our country only abandon the international convergence of fair value and replace the traditional historical cost measurement attributes.

Secondly, there are differences in accounting objectives. The accounting objective determines the accounting standards system. The accounting circle has two major accounting objectives: one is "fiduciary duty view", and the other is "decision usefulness view". Countries in favor of the former one, emphasize the reliability of property information, therefore praising the "historical cost"; and the countries which adhere to the "decision usefulness view" make financial statements and related decision-making data important to investors and creditors, so preferring to the fair value measurement model. At this stage, most of the shares of enterprises in China are more concentrated, especially on the phenomenon of "single dominance" of state stock. The enterprises pay more attention to whether the management has fulfilled their fiduciary duties effectively. This determines that at this stage China's accounting target is mainly "fiduciary responsibility view", so the historical cost measurement model is more acceptable for Chinese enterprises. On the contrary, in the western developed countries with dispersed ownership, so many investors hope enterprises to provide strong correlation information for investors to make more effective decisions. Thus, the common implementation of "decision usefulness” is valued at fair value. Therefore, the accounting objectives of China's accounting standards at this stage choose to abandon the internationalization of the practice.

Thirdly, the accounting concept of determining earnings has not changed. At this stage, our country mainly follows the traditional accounting concept, which holds that the income is determined by the income and expense view. Therefore, the accounting standards in China emphasize the real transaction and the historical cost measurement, and the enterprise's net profit is closely related to the cash flow. But after the process of the development of international financial derivatives, financial derivatives have been recognized since the initial cost is very small or none, so insisting on "revenue expense view" will allow enterprises to face enormous financial risks in the case without the knowledge of the future. Therefore, led by the FASB standards institutions began to use the "asset liability view" to determine the benefits. "Asset liability view" confirms and measures the value of assets and liabilities as the core, and whether and how to confirm and measure the income and expenses depend on whether related assets and liabilities should be confirmed and measured. 
Therefore, with the rise of the "asset liability view", the developed countries in the West have to follow the fair value instead of the historical cost measurement, which makes the enterprise's net profit and cash flow not necessarily related. Therefore, at this stage, China has not yet achieved internationalization from the accounting concept. Of course, the actual operation will not follow the western developed countries.

Fourthly, the supervision system is not perfect. After several hundred years of market economic development, the western developed countries have a relatively complete legal and regulatory system for the supervision and management of economic matters. Therefore, these countries can gradually and smoothly promote the measurement of fair value. But at this stage, China's regulatory system is not perfect, the Ministry of Finance and the Chinese Securities Regulatory Commission and Auditing Departments at all levels of the enterprise accounting supervision power are limited, the legal penalties for counterfeiters are not strong enough, so that enterprises often take the fair value to make up the financial statements. Therefore, it is not yet ripe for the implementation of fair value at this stage in a comprehensive and international way.

(3) After 2006, returned to the road of international convergence.

In February 2006, according to the needs of China's economic development, the Ministry of Finance formally issued a new enterprise accounting standards system. Among them, it is clearly stipulated that fair value should be used as an attribute of accounting measurement, and fair value should be used in 17 specific accounting standards. It can be said that on the issue of fair value, it has returned to the road of convergence with international standards. The main reason is that the domestic macro and micro economic environment has undergone major changes.

First of all, China's financial and securities market has certain development and progress, the derivative financial tools are increasingly numerous, the reform of non-tradable shares of listed companies has also been in full swing, QFII and QDII have emerged, China economy's joining into the world economic cycle is more deeper than ever, and has a broader scope. These changes have objectively promoted China's accounting standards to return to the path of international convergence, and reused the fair value of information relevance in the choice of measurement model.

Secondly, the economic composition of today's world is quite complex, and asset prices, tax rates, interest rates, exchange rates, and other factors will have an impact on the value of the enterprise. If we still choose a more stable historical cost measurement model and ignore the changes in enterprise value caused by changes in the operating environment of the enterprise, it will mislead the users of the enterprise information and make them make wrong decisions. Therefore, the introduction of fair value, will promote China's enterprises face value changes, timely response; regulatory authorities, can also increase the risk of crisis prevention and management awareness; to our whole economic system, it can promote financial innovation and financial market stability and prosperity.

Thirdly, China's accounting standards after a series of twists and turns in the process, have been gradually clear it is necessary to strengthen the development of convergence with international practices, but also adhere to the principle of seeking truth from facts based on their actual situation. Therefore, in 2006, the fair value of the new accounting standards was not arbitrary, but treated differently depending on the specific circumstances. For example, the guidelines say that historical costs are still used when reliable information is not available to determine the fair value.

Fourthly, the current enterprise value based on management (Value Based on Management) has attracted the attention of investors. Investors are no longer concerned only with how much they have invested, but more 
importantly, whether the current value of the business factor changes. In fact, the investors demand to expand the enterprise management accountability and extension, and also represent the Chinese accounting information has been changing gradually from the "accountability" to "the international trend of asset liability view". The transformation of this concept will inevitably require China's accounting standards to re-employ the fair value measurement to adapt to the situation of convergence with international accounting concepts.

Fifthly, the era of knowledge economy has arrived. Unlike the traditional economy, which emphasizes the management of hard assets, knowledge economy focuses on the measurement of the value of soft assets such as intellectual property rights. The characteristic of soft assets "is" small investment, big output power. Relying on the historical cost measurement model can only reflect the "soft asset" "input", but the fair value measurement mode can improve the competitiveness and creation, and force enterprises to strengthen the value, namely the "output” management of "soft assets".

(4) After 2014, the era of tight convergence came.

For all of the fair value measurement in the international financial reporting standards an establishment of separate specification is required or permitted. For reducing the complexity and improving the consistency of application, FASB and IASB decided to develop the convergence of fair value measurement guide. On May 12, 2011, IASB issued the International Financial Accounting Standards No. 13-fair value measurement (IFRS13). Accordingly, the Ministry of Finance of China promulgated the first fair value standard, accounting standards for enterprises, No. 39 (CAS39) on January 26, 2014. CAS39 is basically consistent with IFRS13 in content and achieves the goal of international convergence of China's accounting standards.

\section{In the Context of International Convergence, the Future Outlook of Fair Value Usage in Chinese Accounting Standards}

\section{The Measurement of Fair Value Will Develop With the Progress of Society in the Future}

According to the development of fair value accounting, fair value accounting information is more and more favored by investors and other information users because of its higher relevance than historical cost. At present, the use of fair value has expanded from the financial field to the traditional areas, including long-term assets and other historical costs, and has greatly replaced the historical cost measurement model. Then, whether fair value will occupy the absolute advantage in the implementation of the international accounting standard in the future? First of all, FASB thinks that fair value accounting should be widely implemented, and it needs a breakthrough in relevant accounting theories and methods. For example, determining the fair value of the current international accounting standards and FASB based on real facts can be divided into market transactions and price assumptions based on virtual transactions, and the latter depends on derivative financial instruments to improve the research on econometric model. With the rapid development of computer technology, the accounting profession in the future should be able to solve the technical feasibility of fair value measurement. With the development of world technology, China's accounting standards will promote the application of fair value accounting method to a deeper and broader level, thus it is becoming closer to international practice.

\section{The Development Prospect of Fair Value Depends on the Change of the Economic Environment in the Future}

As the financial industry in the western developed countries in the national economy and the role of increasingly significant, and the fair value adapted to the accounting measurement methods by these countries 
has been highly valued. According to statistics, by 2002, accounting standards in international accounting applications accounted for about $73 \%$ of fair value. And because the international financial activities have become increasingly frequent, all kinds of financial derivatives innovation, especially the global financial crisis was a wake-up call to the world, which creates a favorable external environment for the fair value measurement model to replace the historical cost measurement model dominant in the accounting methods in the future. Although China's economy lies on the level of developing countries, with the further development of reform and opening up, the market economic system will further improve the domestic financial industry and international standards and integration, and create an environment which is more suitable for the use of fair value in the future. China will keep up with the international convergence of accounting standards in relation to fair value of the accounting standards.

\section{Fair Value Will Emerge in a Constantly Innovative Mode}

The economic forms of the world continue to develop in a complex and changeable direction. At the same time, the users of accounting information will not simply ask for reliability or relevance, but hope to have both. Fair value measurement model has its advantages and disadvantages. Some scholar once suggested that "there is no pure accounting measurement model in the future, but there is only an accounting measurement model which is based on some measurement attributes and supplemented by other measurement attributes.” Obviously, in order to meet the requirements of the economic development of our country, the traditional historical cost measurement model will not only be replaced, but replace measurement model with a new measurement model of multiple measurement attributes which use mainly the fair value and the historical cost measurement as a supplement. This is a new development that China's accounting standards and international accounting standards will face.

\section{Conclusion}

In a word, the development and application of fair value in China is proceeding with the development of the reform and opening up of the country. The final goal of China's accounting standards is to serve the national economy. Thus the attitude of the fair value accounting standards in China should be based on national conditions. We must unswervingly go to our country's own economic development road, not blindly copy other countries' international practice. Additionally, adapting to the development trend of world economic of integration, realizing international convergence when conditions are ripe, so as to promote the positive effect to our economy.

\section{References}

Chang, H. (2004, January). Fair value measurement research. Accounting Monthly.

FASB. (2000). SFAC NO. 7.

FASB. (2007). FAS 157.

IASC. (1999). International Accounting Standards No. 39—Financial instruments: Recognition and measurement.

IASB. (2011, May). IFRS 13-Fair value measurement.

Liu, Y. T. (2009, June). The reform and development of Chinese accounting. Financial Supervision.

The Ministry of Finance. (2014). CAS 39-Fair value measurement.

Xu, P. H. (2006, February). The evaluation and application of historical cost and fair value measurement attributes. Accounting Friends. 